\section{Seismic warnings hit home}

\section{Buffalo, New York}

THINk of earthquakes in the United States, and you think of California. At least Californians do, and they still react angrily to the mention of a $\$ 50$ million earthquake research centre on the East Coast campus of the State University of New York at Buffalo (SUNY). Nearly five years after the National Science Foundation (NSF) snubbed California by making New York the National Center for Earthquake Engineering Research (NCEER), West Coast researchers hint darkly that the NSF's decision was due more to the fact that former NSF director Erich Bloch is a SUNY-Buffalo alumnus than to any great need for an East Coast earthquake laboratory.

But over the last few years, NCEER has turned out to be adept at doing one thing that might well have been beyond the abilities of any California laboratory: convincing the East Coast political establishment to take earthquakes seriously.

Due in large part to efforts by NCEER researchers, Connecticut and New Jersey now require new buildings to be earthquake resistant, as does the city of Memphis, Tennessee, and its surrounding county. The state of New York is considering new measures. And now New York City, after long consultation with NCEER, is preparing a new building code that would require buildings to be able to withstand an earthquake of up to magnitude 5.5 on the Richter scale. "Once New York City goes, the rest of the East Coast will follow", predicts civil engineer Carl Costantino, a NCEER collaborator at the City University of New York.

The chance of an earthquake like last year's San Francisco tremor (magnitude 7.1 on the Richter scale) hitting the East Coast is slim, by most estimates, but not as slim is it was once thought.

Recent research by the US Geological Survey suggests that there is a $40-60$ per cent chance of an earthquake of at least magnitude 6.0 in the eastern United States before 2020 (see Science, 249; 21 September 1990). The most violent earthquake in US history took place in the New Madrid area of Missouri in 1811, and Charleston, South Carolina, was virtually levelled in 1886.

In the New York City area alone there is a better than even chance of a magnitude 5.0-5.5 earthquake in the next $10-15$ years, according to NCEER researchers. Although an earthquake of that magnitude is unlikely to damage skyscrapers and other large modern buildings, smaller and older brick or stone structures could collapse without warning. One study suggested that a magnitude 6.0 earthquake in the New York City area could cause direct damage of $\$ 11,000-\$ 25,000$ million, neglecting fire and human costs.

A NCEER team that visited Soviet Armenia shortly after the catastrophic earthquake there in 1988 found that simple techniques such as reinforcing roofwall connections and inserting steel rods into the walls could have prevented much of the destruction. In the United States, the researchers began to publicize parallels between eastern US cities and those in Armenia, and found a receptive audience. As NCEER executive committee member Klaus Jacob put it, "a few pointed primetime evening news TV essays finally broke the ice". New York's building commissioner promptly called for an expert committee to draft seismic provisions.

Since then NCEER researchers have campaigned tirelessly, using every opportunity to drive the point home. They assembled a team to visit San Francisco NATURAL HISTORY MUSEUM

\section{Who will buy?}

\section{London}

LoNDON's Natural History Museum, apparently undismayed by criticism of its corporate plan, is distributing its latest mailorder catalogue in good time for the Christmas trade. Many Londoners found the 32-page colour catalogue falling from their newspapers at the weekend.

Called the Catalogue of the Unusual, the document features over 160 gift ideas from the inexpensive (a set of car stickers at £2.95) to the extortionate (limited-edition dolphin sculptures at $\mathbf{1 4 5}$ ); the frankly tasteless (both the above) to the arguably exquisite (illustrated playing cards at $£ 14.50$ per set); the frivolous (armadilloshaped sleeping bag, $£ 99.50$ ) to the ingenious (an electrolytic digital clock powered by two potatoes, £12.95); and the indulgent (silk tie with M. C. Escher design) to the practical (the prizewinning 'green lensman' portable field microscope, with optional SLR adaptor and case for a very reasonable $£ 122.90$ ). There seems to be something for everyone.

The traditional festive plastic dinosaurs (now relegated to a subfusc item on page 26) are largely replaced by a superabundance of designer-print leisurewear and silver jewellery. This marks the transfer of the museum's mail-order business to an external company, Design Marketing Ltd of Andover, Hampshire.

The concept follows similar ventures by other museums such as the Smithsonian Institution in Washington, DC, (whose sculpture of a group of meerkats was a bestseller, and is now available from the Natural History Museum catalogue at $£ 32.95$ ). The American Museum (Natural History) has a nice line in dinosaur-print silk ties. after the 1989 earthquake and sponsored the travel of four members of New York City's code-writing committee to accompany them. The committee recommended a seismic code almost immediately on their return.

NCEER officials are currently considering a small demonstration project in New York City for the centre's advanced technology, such as sliding foundation bearings and active controls that use movable weights or hydraulic braces to counter the forces generated by an earthquake or strong winds. And next year, in the first such US project, NCEER researchers will equip an existing skyscraper in the American southwest (details of which have not yet been released) with wind-resisting active controls. If successful, the demonstration will no doubt go far in convincing the construction industry to consider similar measures in other hurricane- and earthquake-prone areas.

Christopher Anderson USSR-US UNIVERSITY

\section{Academic exchange}

\section{Moscow}

THE first 60 students have now been enrolled in the independent SovietAmerican University, which held an opening ceremony here last week. The objective is to exchange teachers, rather than students, between the Soviet Union and the United States, perhaps economizing on costs but also providing a novel environment for teachers.

The university, which has the backing of President Mikhail Gorbachev and President George Bush, is the concept of people such as Yuri Osipyan, vicepresident of the Soviet Academy of Sciences, and Professor Edward Lozanski from Washington, who said at last week's ceremony that the project "seemed like science fiction 12 months ago".

For the immediate future, the two sides will exchange teachers in the fields in which they are themselves strong. The Soviet side will at first offer experts in, for example, theoretical physics, analytic mathematics, Slavonic studies and music education. The United States will send experts in computer science, economics, business and management.

The new university will be housed initially at the Moscow State University, which will be responsible for awarding qualifications. The plan is that the university, when independent, will offer fouryear courses, as in the United States. Funds are being provided by the USSR Academy of Sciences, Moscow State University and the USSR State Committee for Public Education, as well as by several private funds, foundations, companies and independent organizations in the United States.

Valeria Prut/

Novosti, Moscow 